\title{
The Desire to Disappear in Order Not to Disappear
}

\section{Cairene Ex-Prisoners after the 25 January Revolution}

\author{
Maria Frederika Malmström
}

\begin{abstract}
This article tells a story of the aftermath of the 'failed revolution' in Egypt through the prism of sound and gendered political prisoner bodies. It created embodied reactions among Cairene men-years after their lived prison experiences-in which depression, sorrow, stress, paranoia, rage, or painful body memories are prevalent. Affect theory shows how sonic vibrations-important stimuli within everyday experience, with a unique power to induce strong affective states-mediate consciousness, including heightened states of attention and anxiety. Sound, or the lack thereof, stimulates, disorients, transforms, and controls. The sound of life is transformed into the sound of death; the desire to disappear in order not to disappear again produces 'ghost bodies' alienated from the 'new Egypt', but from the family and the self too.
\end{abstract}

Keywords: 25 January Revolution, affect, bodies, Egypt, prisoners, senses, sound, violence

\section{February 23, 2014}

I can't express what is going on inside me without sadness and grief for what we are in. They now want us to die twice. Once alive on their hands in their prisons, and another time by God's fate and the end of our life and I see that the second way is better for me now. I don't want to be alive in my grave. The 'prison' for me is like a grave exactly and worse.

A prison letter from a student. Below is an excerpt from detainees in cell number

3, Helwan police station (the Nadeem Center 2014).

The voice of torturing the convicts breaks our hearts and brings tears to our eyes.

This is part of a whole and a drop in a shower of sadness. 


\section{Introduction: Those who must live and those who must die}

This is the sonic story of Egypt behind bars-about the disappeared, the absent and the forgotten political bodies. The aftermath of the heated uprisings created many embodied reactions among activist Cairene men-many years after their lived prison experiences - in which depression, sorrow, stress, paranoia, rage or painful body memories are prevalent. Vibrations, or sonic infrastructures, can both shape and constrain the actions of individuals and groups because vibrations are sensed in the body and have the power to mould a gendered self. Infrastructures, as Brian Larkin (2013: 329) points out, are 'matter that enable the movement of other matter' and are the Egyptian state's tool of expulsion. Sound, in turn, or the lack thereof, stimulates, disorients, transforms and controls. And as Steve Goodman explains, affect suggests:

the potential of an entity or event to affect or to be affected by another entity or event. From vibes to vibrations, this is a definition that traverses mind and body, subject and object, the living and the non-living. One way or another, it is vibration, after all, that connects every separate entity in the cosmos, organic and nonorganic. (2012: xiv)

As an object, sound has a particular status. Sound is measurable, which means it is material, if invisible. It permeates our bodies and the environments in which we live. We cannot keep our ears closed or sounds out. Sound also creates environments: revolution takes place largely with the energy generated in chants and songs; church bells and the Islamic call-to-prayer sacralised space. By focusing on the understudied realm of sound, we gain a fresh vantage point from which to interrogate the ways individuals and collectives experience navigate the complexities of self- and homemaking during forms of displacement.

What is particular to the post-trauma context of engagements with the aural that I consider in this article is rhythm, as Henri Lefevbre and Catherine Régulier point out, 'we are only conscious of most of our rhythms when we begin to suffer from some irregularity' (2004: 77). Temporality and frequency clearly influence these affective flows. Sonic intense embodied lived memories of the insecure political bodies of traumatised men may return unexpectedly in new contexts and new times - those can be activated and deactivated-because the "[porous] sound body is a material body that resonates (with) its environment, creating and conducting affect' (Kapchan, 2015: 41). The effects of trauma living on through sound and sonic memories are inscribed in the political gendered bodies of today, and maybe present in the bodies of future generations, because of sonic transmissions of affect (Brennan, 2004) both as a destructive force and as a healing and post-traumatic growth. These effects of trauma living on through sound and memories of sound is inherently related to masculinity. As one short example from my ethnography: the feminisation of the male body in prison (e.g., nickname, the torturer who treats his victim as a mistress, the allusion to male genitals). ${ }^{1}$ 
Through my emphasis on sound and listening, I contribute unique empirical knowledge about the material and affective conditions and consequences of disappearances and detention. At the heart of inquiry is the role of sonic infrastructures in producing a sensorial form of revolutionary permanence in the male body. Such knowledge is vital for the much-needed advancement of our theoretical comprehension of the sensory consequences of political conflict, the aftermath of revolutions and of political agency within these processes. In this text, affect theory draws attention to how vibrations - being important stimuli within everyday experience and having a unique power to induce strong affective states-mediate consciousness, including heightened states of attention and anxiety. Instinctively we understand the sounds of violence, aggression, and fear: We run away, take cover, protect ourselves, retaliate. We also intuitively recognise the sounds of tranquillity and safety. We move through these forces that move through people and produce direct emotional responses as we move through the world. In looking at resonance, vibration, energy, and sound, we are simultaneously profoundly material and intensely ethereal.

There are ever-present sounds in Cairo that are connected to gendered bodies, such as the car horn associated with drivers (cf. the film Cairo Drive), the sound of tuk-tuk, heavy sounds from weights at the gyms, the muezzin call to prayer, shops with mahraganat (electro/popular) music, the clinking of the gas man's tools that announces the availability of new canisters close by or by the specific sounds of street vendors at markets. In this context, it should be said that the dynamics of gender, class, age, ethnicity, disability, political, religious and sexual orientation, and other forms of social stratification are intimately connected to different sounds in the cityscape and should be thoroughly analysed in relation to power, time, and context. For the men in focus in this article, exposing themselves to the noisy streets of Cairo, in Sisis new Egypt, after months or years of overwhelming experiences in prison, is for many simply not doable. They have not only, like the rest of political activists, lost their hope for their new Egypt, but are most often traumatised because of the prison 'remedy' commanded by the dictatorial regime of Egypt. The technology of feeling is not intentional; even if we are together with other bodies, it is central first to inquire where are we in the world and what we experience, not least physiologically and psychologically. The sound of torture or those generated by fellow prisoners produce affect in a certain way, and it would be a total contrast to the experience of following a similar scenario on TV individually at home or in a group at a cinema or theatre, since it would be a totally different affective moment. Thus, the body is formed through experiences, and the body always remembers (Malmström 2019). Revolution and counterrevolution live on and continue to mark bodies through embodied memories of the sonic. Sonic body memories are wounds that do not heal because the self can fragment as a result of attempting to cope with extremely difficult experiences. 


\section{Inspirational studies of affect, sound, and gender}

Affect can be understood as both 'contact zones'-spaces where something happens-and 'social experiences in solution'-the events that occur in the zoneswhere the 'solution' can change its nature and qualities as a result of the 'flows of power' unleashed within it (Stewart, 2007:2-3). As with all elemental forces, affect can be understood as possessing the qualities of both matter and energy-that is, the force can be considered as having both non-material and material substance, as a particle and as a wave and indeed both at the same time. If we consider the physical impact of sound waves, even on deaf people, we can understand how waves produce substantive and psychological reactions on those with whom they interact (LeVine and Malmström 2019: 139). The vibrations are there, even before they become perceptible to the ears. The framework of affect theory allows us to assess transitional societies by rethinking the relationship between body and mind. By exploring the materiality of affect I mean questioning both how material surroundings provoke emotional responses and how affect is materialised in the body. Such a multi-paradigmatic theoretical approach that takes into account both affect and materiality enables me to formulate new questions and thoughts and to develop a methodology of research that advances our understanding of revolution and its aftermath. By acknowledging sound, whose vibrations are material and can be measured as infrastructures, we can explore vibrations as sonic infrastructures; as tools of techno-politics. In this article, I focus on the forces of affect produced by vibrations-sonic infrastructures in the Egyptian post-revolutionary context.

For me it is key to explore the production of masculinities as an open-ended life process, actively shaped by both agency and victimhood, and to affirm the role of embodiment (Malmström 2015) and the forces of affect produced by sonic infrastructures. I am also inspired by two scholars in the field of sound, space, and the making of certain masculinities, Shenila Khoja-Moolji (2016) and Andrija Filipović (2018). Khoja-Moolji explores how sounds play a critical role in the production of gender and race. In her article about sounds of racialised masculinities in the Anglophone sphere, she analyses their links to affective pedagogies of language and chants. Filipović, in turn, examines how straight masculinity and queer subjectivities are being made in affective relations to the sounds within various spaces, challenging the 'boundaries' between the private and public in the urban soundscape of Belgrade.

\section{Fieldwork in Cairo}

During my fieldwork, I listened to the soundscapes ${ }^{2}$ of displacement in the context of censorship, the war against 'terror', resistance, and a police state. I investigated how sounds in prison and afterwards contribute to an exaggerated sense of displacement and to a collective and individual loss of hope of an imagined new national home. I paid attention to how sonic resistance in prison work towards strengthening peoples' sense of belonging. I also focused on the way these men talk 
and express feelings, how sound both reflects and helps generate affective states, including bodily postures, in relation to what was-the present-and the future. I paid attention to narratives and objects relating to sonic memories, exploring the lingering affective power things still might have: how, for example, memories are preserved and communicated through affective relations to specific objects, such as batons, keys, blood, and clothes. In light of the extraordinary politically sensitive nature of the subject matter, I have decided not to provide any further information about my interlocutors to ensure their safety. Because of the precarious security situation, it is ethically problematic to present detailed ethnographic findings, and those I present in this article were selected carefully. ${ }^{3}$ In addition, to further protect my interlocutors, I have chosen prisoners' letters published by the Nadeem Center for Rehabilitation of Victims of Violence and Torture in Cairo, founded in 1993, to treat the effects of torture in Egypt (Michaelson 2018).

\section{Prisoners in Egypt}

'We are like cockroaches for them, Maria' (Ahmed, September 10, 2020)

Since the ousting of President Morsi during the summer of 2013, President Sisi's autocratic regime has created a sense of belonging among some Egyptians while simultaneously producing a widespread sense of conflict and disorder in which Muslim Brotherhood (MB) supporters, revolutionaries, and liberal activists are constructed as 'enemies' and 'terrorists' and are suspected of a lack of loyalty to the nation. MB followers are perceived as insufficiently patriotic and as part of a political Islamic movement emotionally oriented toward the global Ummah (the worldwide community of Islam) rather than toward Egypt. For Nationalists, the national boundaries must be protected and kept. The other two categories are perceived as criminals and enemies to the state (Malmström 2019).

More than one hundred thousand Egyptians have been imprisoned since the January 25, 2011 revolts, and many have died because of the harsh conditions in prison. Upon political detainees, many who must continue several years of socalled semi-imprisonment, where they are forced to spend their evenings and nights (12 hours of every day) in neighbourhood police stations. How do sounds work towards eroding embodied senses of home and stability and creating tension, fear, and instability during and after detention? The majority of the men I collaborated with have been detained and/or imprisoned as perceived enemies of the state. Some of them endured several months or up to one year in an isolated cell, and many were denied family visits and were exposed to torture, including acoustic violence (see also Papaeti 2020, for the institutionalised use of music and sound in torture). However, the isolated cell is also a space of unwanted silence. So, how can one stay agential and sane? How might one navigate between being alone and loneliness? One way is to make sounds or listen to the sounds inside and outside the cell. Mohamad told me that he was in solitude for several months (except when his 
family visited him every second week). The guards allowed his family to give him books and so he read them aloud to stay sane, since the sound of his voice made him feel less alone. Another man, Mustapha (permitted a smaller network than Mohamad), made friends with the cockroaches in his cell. He began to listen to the sounds of their movements. He even took care of them by feeding them his hair. To avoid further severe torture, he did not speak with the guards when they entered his cell. However, listening to sounds may also produce further fear. One common punishment, former prisoners informed me, was for the guards to not touch them for prolonged periods but instead have them listen to the sounds of fellow prisoners being tortured or even force them to witness torture with their eyes and ears, for example, the electrocution of their tongues or genitals.

During the fall of 2017, I met Rami for the first time. His stress and instability were observable. He was, during this time, only twenty-six years old but had already had many prison experiences. He was very active during the 2011 uprisings, a member of the 6 April movement, but is today politically inactive, according to himself, because he has severe psychological problems and must take sedatives. He told me that he was in constant fear for three years from 2011. Rami remembered his first detention very well, even if it was short. He was not blindfolded, but two police officers held him tight while a third 'criminal' man (it is common to use fellow prisoners or thugs) beat him severely. He had been detained and beaten so many times and for long periods between prison times that he was too afraid to go back home because he was afraid to be detained and tortured again. At the end of our first meeting at a bar, as he wanted to drink beers even though he should not because of his medicines, he had tears in his eyes, and he told me in a silent sad voice: 'Maria, I want to kill myself, I cannot cope anymore. The other day when I waited for the subway I wanted to jump, but then I got so scared'.

Former prisoners are never free from their previous painful lived experiences but carry these traumatic events through life, even those who have managed to leave Egypt. Ahmed, the same person of the opening quote, for example, whom I first met in Cairo a couple of years ago, is a former political activist and prisoner (he was detained in 2014). He left Cairo shortly after our meeting and now lives in Europe. He has a three-year visa but is worried as to what will happen after since, as he was informed by his Egyptian lawyer in 2020, he is on the detention list again (his case never closed but is instead pending). He is confident that he will be detained at Cairo airport if he travels back to Egypt. 'I miss my family, Maria, every day. Here I do not socialise with Egyptians. I do not want to. Years after he was released from prison, his brother was imprisoned (in Sinai). When I asked why, Ahmed ironically smiled, and with a calm voice: 'This is how the system works in Egypt. To show off [to the outside world] that they are strong and are in control of terrorism. But they are not. They can never catch the real ones. Instead, they imprison young innocent men from Sinai, like my brother, for nothing.

Ahmed wrote a poem in English on his phone when he was still living in Cairo (since it is safer if detained by the police). He still carries the text and wanted to 
share it with me in 2020. I have not edited it, but the poem is quoted exactly as it stands in the original.

Everyday I wake up my nightmare and my reality are the same thing Everything I eat has bitter taste.. And I don't taste anything..

I have anxious of diseases.. And I can't live without antibiotics or sedatives

Everyday I fall down.. Everyday new disease, thinking brought it me down..

I got out of the situation. I went in another situation..

Thinking and emptiness are Motherfuckerz..

I don't know are these physical diseases or Psychiatric diseases..

I feel both live inside me stick in me..

I feel I'm crazy, sick and imprison in me..

I feel all my body boiling.. I stay at home roaming and rolling..

I feel I'm not balanced.. I want that case will be cured

With illusion of diseases I'm believed..

I feel my body is dead.. I don't feel sever pains in my head

But I still have the same case..

Same vomiting.. My body refuses drinking and eating

Refuses everything but vomiting.. No more pains no more feelings

I saw the death.. I passed nightmare level and also to scream without voice..

I saw the death.. I carry too much on my shoulders.. My soul imprisoned inside a

box.. I saw the death..

My reality is a motherfuckin' wicked nightmare..

For any body on this fukin' planet whoever who are..

So what do you think about my nightmares are and that bar?

I saw my body have been shred many parts in front of me..

And my blood running on the floor everywhere.. Was bloody view

My body gathered every parts as one part again...

And I have a sharp knife in my hand..

I read and I watch every thought inside me

I saw a buried cut throat inside me

Wants to cut every motherfucker's neck

And neck of every officer who imprisoned me

I'm inside a fuckin dark room can't see anything but a cup red blood in

my hand... The only thing I can see.. I drank it I saw the room with red light

with 3 walls no exits.. Just one bed behind bars.

When I was prisoner.. I did read a line written.. Prisoner is the brother of insane...

I hit my legs at walls I hit my hand at my head.. I hit my head at my bed..

I feel I'm like in a rehab I'm off.. since 2 years ago my brain is off

No I'm not in rehab... Who are in rehab got cured Psychology..

But I'm in revers rehab I'm torn physically Psychology..

No I feel I wanna go to real rehab otherwise I will live insane... Yes I'm

Insane.. 
Maybe its better to live prisoner and Insane... And I know your stupid realities and I laugh at all of you.. You know I'm happy I'm careworn.. Even though better than to live your fucking stupid life as naive whore.. I know the story is fuckin scary and frightening story... But I keep going And buy some milk for streets dogs and cats and thirsty... (sic)

Ahmed does not separate his prison experiences from his activities during the 25 January revolution. When he talked about his prison period, he could not stop himself from talking about what he went through during the uprisings. He told me, for example, about all the young people who died: 'So many died just beside me, Maria. There are still in my head'. He also talked about the wounds from the rubber bullets on his legs, the many escapes from tanks, and the ones who did not manage to run fast enough. Ahmed told me during the fall of 2020 that he is 'fucked in his head'. He has chronic stomach pain and said that he also developed irritable bowel syndrome (IBS), which is a chronic condition. Signs and symptoms include cramping, abdominal pain, bloating, gas, and diarrhoea or constipation, or both. Its cause is unknown - it might be oversensitive nerves in the gut, stress, and a family history of IBS: 'The stomach is the second head. If something has happened, you sense it in your stomach. It is aching every day'. Ahmed still takes sedatives, something he started right after the nineteen days in prison. He sometimes has aches in his knees, since he was heavily abused with cudgels. Ahmed giggled: 'Maria, you know the stick policemen have? It is like the size of a dick'. I still do not know why he talked about the cudgel as male genitalia. He was never electrocuted, but they took him to a room with equipment as part of forcing him to confess things that never happened. Ahmed explained that it was not only the traumatic time with torture every evening and night in prison, where the sounds of his own screaming or that of fellow prisoners accompanied his stay, but his life afterwards outside prison. His whole life changed since he was forced to sign documents to never again work with his occupation, which led to deep depression since he loved his work, and poverty since he could not find another job. He told me: 'Everything was destroyed after prison-my whole life-my career-my survival-my body'. Ahmed was forced to be financially dependant on family and friends for years until a friend from abroad invited him to stay in her country. Ahmed wrote the below note after his period in prison. I have not edited it. The note is quoted exactly as it stands in the original:

What am I doing here? I know I don't belong here. I don't belong anywhere. They broke me, they broke my pride. I will never be the same again. I don't trust anyone, because they let me down. Everyone will let me down in the end. All the good people I knew left. Left to their safe places. I stayed here alone. Vodka became my best friend. She helped me to sleep, she helped me to forget. She became my lover. Always with me when I needed her. Gave me her warm hug, that filled me all inside. It felt sooo good......until the moment when she also betrayed me. I got sick. I felt I was dying. She was my help and then became my nightmare. My body refused to live. She led me in the worst shadow in my life. I couldn't get rid of this. She poisoned my thoughts, made me hate my life. All I felt was pain. Pain through every single cell 
of my body. I was crying for help but nobody came. I don't know how long I stayed without food, maybe days, maybe weeks. Half asleep, fighting the nightmares. Don't remember anything from that time, one big black hole. Sleep, vomit, sleep, vomit. I remember I had a girlfriend in my previous life, but she disappeared. Like all the others. I had no one (sic).

Ahmed talked with psychologists at the beginning of his stay in the new country, who informed him that he has post-traumatic stress disorder, and he continued to take sedatives. He has nightmares about police beating him and chasing and detaining him, but less than in Cairo, when he had those dreams every night. Ahmed let me know that it is the same dream repeating itself:

I am chased by the police, I can hear their voices and the sounds of their boots, but I cannot see their faces. I can see my own scared breath. I always wake up in the middle of the night, sweating and shaking. Sometimes I try to calm down by recitation. Often it does not help, so I take the whole bunch of pills to stop shaking and to able to fall asleep again

Today he still wakes up every night for a couple of hours, and even if he does not think about anything, he cannot sleep. He knows he has changed, he is never satisfied with anything anymore, and he cannot make any decisions. He does not know the way forward, except that he wants to succeed with something in his life so the Egyptian regime does not win. He also said that he wanted to make a statement. To write something so the world would know what is happening: 'But I cannot, Maria. How could I do such a thing? I am afraid they will harm my family'. I know Ahmed quite well, and I perceive him as continuously restless and stressed but at the same time as strong, smart, and dedicated. When he was detained in 2014, he was put in the same cell as criminals and with other political activists. However, they respected him, he told me, since he had informed them that they could not steal the clothes he wore even if they beat him severely, it would not matter, since the police entered every late evening or night and tortured him in front of them. He would not give up easily. He was strong, he said to me. The fellow prisoners respected him and wanted to hear his story, since they were surprised that even after heavy beatings he never collapsed. He continued: 'I have criminals in my family, Maria, and I come from Sinai. I am strong. I know how to survive in the desert, and I know how to survive with criminals'. One police officer came every late night to torture Ahmed: 'It was like a routine. This guy kicked, punched, and struck me with his baton and he said: "I'm going to fuck you up like this for as long as you're here". One late night, in front of fellow prisoners, the same police officer directed his gun to Ahmed's head and shouted that he would kill him and dig him a grave in the desert and that no one would miss him. Ahmed thought this was the end of his life, since this guy did not have any restraint, and he was very upset since a relative had died in Sinai. 'It is not my fault that I am from Sinai', he continued, but the guy did not listen. Ahmed also remembered the shame and humiliation, and gave one example of threats during beatings: 
Huh, huh, basic rights? You are human shit, you have no rights. Repeat after me-I am human shit, I have no rights. I was made from shit and I will die as a piece of shit. I said-repeat motherfucker or we will use the electric wire. [and I was forced to repeat his words]: I am human shit. I was made from shit and I will die as a piece of shit.

In the end, another police officer close by entered, gently removed the gun, and told his colleague to calm down. In addition, Ahmed said the sounds in prison, and afterwards, were extremely tough. There were constant screams from other cells or outside, where they partly could hear and gaze at torture through the small window with bars. He particularly remembered one time when a man was handcuffed from behind, and his handcuffed hands were attached to the roof (carrying the whole bodyweight in an awkward position). Another brutal sound he remembered was the one produced by the police officer who loved to torture him. 'It was like I was his mistress. Every night he came for me and tortured me in the cell-kicked the iron door with his foot and thereafter opened the door. If the prisoners who slept on the concrete floor did not stand guard when he opened the door, he would kick them heavily'.

Below I have selected some excerpts from prisoners' letters published by the Nadeem Center in 2014 to show further examples of today's Egyptian political prisoners' extreme lived experiences (some are young children) to illustrate the context of sonic ambience, living conditions, daily threats, humiliation, and fear, and sonic torture (see also ADSMP 2020 for testimonies of former detainees who suffered while in detention in the Sednaya Prison during the years of the Syrian revolution). All excerpts are quoted exactly as they stand in the original.

February 19, 2014

After the prisoner check is over it is usually around $1 \mathrm{am}$, the detainees pray and sleep which is a very difficult and torturing process like performing an open heart operation without anesthesia because of the overcrowded number. This is what usually happens on daily and regular basis apart from sometimes when one officer's mood gets disturbed and decides to bring one of the detainees to have fun in a process of humiliation, assault and mockery till his mood is better. The only day that the detainees stood up was when one of the officers insulted a detainee and tried to tie him in handcuffs to be beaten by the soldiers, the rest of the detainees started shouting freedom and banged heavily on the cell walls by their hands till the officers stepped back from the trial of assault that is brutal most of the time. But the next day there were threats for all the detainees that if this happened again the response will be throwing tear gas inside the cells, the thing that didn't terrify us any more, as we daily from 4 am-9 am live in the middle of soldiers shouting during their training and shooting and their training on using tear gas the smell of which reaches the cells and we smell it to the extent that we started feeling that we became addicted to. 
Prisoner at the central security camp at kilo 10.5.

February 25, 2014

Knowing that I wrote before about a case of death due to negligence when a patient was in pain for 6 hours and more and we were screaming but, the detective ordered us to shut up because we were sons of bitches as he said. This detainee died and the paramedics came an hour later!!

Prisoner and journalist in an unknown prison.

\section{March 24, 2014}

Torture is done by suspension on doors, pouring of boiling water and boiling oil, electricity. Some of the detainees are bound by their feet and hands throughout the day in solitary cells for months.

In Azouli prison there is a women's section. You can actually hear their screaming during interrogation.

Prisoner at the Azouli military prison, Ismailia.

March 31, 2014

I was kidnapped from home on the 23rd of January and held at Azouli camp for 27 days during which I was tortured with electricity, beating and flogging with an iron chain. In Azouli prison those kidnapped are suspended for continuous days and nights without food or drink. If one of us screams of thirst he hears the voice of her torturer saying open your mouth so that you may drink; and when the victim opens his mouth an electric wire is inserted in his mouth instead of water.

Prisoner at the Azouli prison.

April 18, 2014

- Can you see anything like this... He asked after putting the blindfold on my face. - No.

-then come with me you son of a $b^{* * *}$.. you will see now.. you will see death you $* * * * \star$ he screamed and violently pushed me I didn't see death. I saw the truth I was seeking.. the truth of the blindfold, the handcuff, the electricity... and the triumph.

\section{The blindfold}

I remained blindfolded for a whole week. El pasha was terrified that I might recognise anything about his identity or the place where they kidnapped me from. The strong Pasha in a God like manner tells me that he is omnipotent, and yet he is scared, like any tyrant, that the people know anything. The blindfold is a must to cover, to hide, to misguide.

The handcuff

"Your hand behind your back you bastards... handcuff them all behind their backs pasha" The armed pasha is leading a brigade of armed men inside a building guarded 
by tanks. Of course he is not afraid we might escape. That is not why he is handcuffing us. What he really wants to ensure that no moment should pass without us feeling continuous pain; slapping, kicking and beating with sticks is not in those short breaks from beating-probably because they are exhausted-they pour cold water on our bodies that become as cold as the dirty tiles on which they throw us.

\section{Electricity}

\section{-Your name?}

- Moh...

-No, your name is Laila, Laila you son of a $b^{* * * *}$. He cut me short with punches that made me drop to the ground where he attacked me with an electric shock to my neck, before standing with his boots... on my face.

I heard many torture stories. All of them begin with a humiliating violent aggression. All tyrants have the same policy. Since the first moment, they drown you in a dirty, ugly pile of torture until you lose your breath and your utmost wish becomes to experience a single minute without pain.

Prisoner and student, faculty of pharmaceuticals, in unknown prison.

Sonic torture is an action of corporeal disciplining as the preceding excerpts show. I assert-not least after listening to many of my interlocutors' narratives about their lived sonic experiences in prison, written testimonies, along with other scholars in the field-that when one body is tortured, all bodies are tortured, since even when the torture is not witnessed directly, it is most probably heard and witnessed aurally. It is a sonic infrastructural torture. There is a lack of literature in the body of affect, sound and prison, but Lawrence Abu Hamdan (2016) also discusses the torture of the collective body, but in Syria (see also Tom Rice's 2016 research about permeable walls in relation to prisoners in the United Kingdom; Barbara Harlow's (1992) research about the dynamics of resistance movements and political detention and treatment of women as political prisoners; and Julie Peteet's 1994 research about prisons' rites of passage into manhood in Palestine):

The prison is really an echo chamber: one person being tortured is like everyone being tortured, because the sound circulates throughout the space, through air vents and water pipes. You cannot escape it.

Lived sonic experiences in prison, and the lack of desired sound experiences (cf. Parker 2019), not only carry information but also produce the listener's sense of self. Infrastructural sounds in prison not only define daily rhythm from night rhythm or indicate activities (for example, the footsteps from the guards or their keys jangling might mean it is time for food or visitors) but may also indicate danger (such as further interrogation or torture). Moreover, the noises may create disequilibrium (through shouts of guards, screams of fellow prisoners, or the slamming of doors), and the sense of an unpleasant 'home' or at least a sense of predictability. The sonic atmosphere of prisons is a punishment (cf. Parker 2019) but may also be used as a form of resistance. So how might we think through understandings of agency from 
a sonic perspective? Whereas detention is characterised by stasis, control, isolation, uncertainty, boredom, fear, and violence, prisoners do not passively encounter these conditions. Quite to the contrary, there are many examples around the world of how prisoners actively navigate detention through individual and collective strategies to endure and resist-and to create an everyday life. If we listening to the social acoustics of prisons, we are able to explore social, cultural, and political experiences and imaginaries. Rice (2016) shows how the UK prisoners shouted to locate one another and connect in an unwanted prison environment. The acoustic is part of the orientation of space, in which the prisoners learn to navigate their surroundings, even if they are immobile. They learn to differentiate between the different sounds in relation to their fellow prisoners, such as whispers, mutterings, screams, and other corporeal sounds. Hence, these men communicate with each other and share information. However, they also demarcate space and claim territory by, for example, intentionally (or not) starting 'lengthy and severe disturbances of one another's sonic space' (Rice 2016: 8). Papaeti (2020: 9), in her work about torture survivors of the military dictatorship in Greece, discusses 'how detainees in solitary confinement faced with imposed silence reclaimed agency through humming, whistling or even coded knocking on the wall'. In Egyptian prisons, whispers have a specific meaning. One common agential act, my Cairene interlocutors told me, is for prisoners to whisper their name to their neighbours, to ensure, if someone was released before the others, they could contact the family to let them know the imprisoned is still alive. However, the family may not believe the friend after such a long time has passed, they might have already buried (and grieved) a body they thought was their loved one, or they may assume the call was part of the torture system, as it had been before. Equally surreal is the day if and when the prisoner is released and calls his family, but they do not believe him for the same reasons.

\section{Conclusion: The living dead}

Through my emphasis upon sound and listening, we move beyond conventional approaches to peoples' experiences of prisons, opening up space to investigate also the non-conscious forces that have a profound influence upon our thinking and decisions in moments of intensity. Attention to the body, our senses, and public affect foregrounds the role of immediate and experience-based forces during times of insecurity and instability. To be forced into solitude for months or the opposite in crowded cells, denied family visits, constantly threatened, humiliated, and beaten with all the encompassing institutionalised acoustic violence or spaces of unwanted silences alter and destroy the bodies of prisoners. The sonic ambience and the lack of sound in prison contribute to an exaggerated sense of displacement long after prisoners are released, and to a collective and individual loss of hope of an imagined new national home, not least because sound systems operate at auditory, corporeal, and sociocultural frequencies. The sonic infrastructure of torture in prison under today's autocratic regime provoke emotional responses of not only loss and nonbelonging but also paranoia, depression, and even death-worlds. The disciplining 
effect of walls, torture, controls, and armed personnel permeates the body and the sound of violence produces an ambience of uncertainty. Hence, the forces of affect are materialised in the bodies of prisoners long after they have left detention-the affect of sonic infrastructures produce porous and broken bodies (in every sense). Furthermore, as mentioned earlier, things have lingering affective power, embodied memories are preserved and communicated through affective relations to specific objects-things that might appear in another context than the prison context when the men in focus least suspect it. Thus, the revolution remains and endures in the body of these men. This is biopolitics of the senses (Howes and Classen 2014). This is also an example of what Achille Mbembe entitles necropolitics (contemporary forms of subjugating life to the power of death), which is 'new and unique forms of social existence in which vast populations are subjected to living conditions that confer upon them the status of the living dead' (2019: 92).

Obviously, aspects of both agency and victimhood are active parts, as described earlier-for example, through making, avoiding sound, or listening to sounds inside and outside the cell. As I have written before, in the context of violence and masculinities in Palestine, it is impossible to talk exclusively about agency or victimhood or to draw rigid lines between these categories-they are blurred (Malmström 2015).

Various kinds of sounds of the state are forces that continuously mould and order the bodies, the senses of these specific masculinities, senses, and their consciousness. It is almost impossible to resist or to forget the power of sound from the state because of daily sonic reminders in and outside prison. Charles Hirschkind, in his discussion of the tension between the nationalist and political Islamic discourses that compete to produce a modern citizenry through pious sounds, refers to an ethical soundscape, arguing that 'contrasting regimes of aural sensibility structure public debate and political life in Egypt' (2004: 132). Similarly, in the context of today's Cairo, the shift in Cairo's masculine soundscape from the revolution and onwards leads to an exaggerated tension of the sort Hirschkind describes. However, this soundscape can be linked not only to modern citizenship (and 'proper' Islam) but also to uncertain stigmatised porous political masculinities (Malmström 2019). It certainly reshapes manhood, and it reshapes nationhood. But it does something additional-it kills the potential self. Former political prisoners are both traumatised and terrified of being detained again, so they do not live a life in dignity or navigate the cityscape of Cairo as they did before the prison experience. They must, for example, avoid the atmosphere of silence at coffee shops and bars (where the ear of the state is always present), avoid silent dawn streets since these men may forcibly disappear by the assistance of security forces, or simply avoid the cityscape since some sounds remind the ex-prisoners of earlier hostile environments, including torture and earlier trauma. What is worse, the men in focus do not feel safe at home. When someone unexpectedly knocks on the front door, especially early in the morning or very late, it might be the state security. The ex-prisoners instead try to stay as invisible as possible, both in a metaphorical and concrete sense. The sound of life for these men is continuously transformed into the sound of 
death; where the desire to disappear in order to not disappear again produces 'ghost bodies' alienated from not only the 'new Egypt' (encompassing a permanent loss of hope of an imagined new national home) but also from the family and the self too.

\section{Acknowledgements}

The research for this article and writing of it were made possible by the threeyear grant from Riksbankens Jubileumsfond (the Bank of Sweden Tercentenary Foundation).

Maria Frederika Malmström is associate professor at the Centre for Advanced Middle Eastern Studies, where, in January 2017, she started a collaborative five-year research project The Materiality of Suspicion and the Ambiguity of the Familiar: Nigerian and Egyptian Cityscapes, together with Professor Mark LeVine and Assistant Professors Ulrika Trovalla and Eric Trovalla. In January 2018, she started the three-year research project Making and Unmaking Masculinities and Religious Identities through the Politics of the Ear in Egypt. She is currently a visiting research scholar in the Middle East and Middle Eastern American Center at the Graduate Center, CUNY, New York City.

ORCID: 0000-0002-6420-1376. Email: maria.malmstrom@cme.lu.se

\section{Notes}

1. It would be of great interest to know the effects of trauma living on through sound and memories of sound is inherently related to expectations of femininity, but since I have not focused on female prisoners during this particular project, I do not know to what extent similar sonic effects of trauma might hold for female prisoners.

2. I employ R. Murray Schafer's (1977) term 'soundscape' in a broad sense. I am aware of the importance of temporality and cultural and contextual differences between noise and sound.

3. The first fieldwork for this three-year project was carried out in Cairo from September 2017 until the end of January 2018, during some weeks in the summer and fall of 2019, and the last through phone during the era of pandemic in 2020.

\section{References}

Abu Hamdan, L. (2016), 'Earwitness the Saydnaya prison'. http://lawrenceabuhamdan. com/blog/2016/8/30/earwitness-the-saydnaya-prison (accessed 15 November 2018).

The Association of Detainees and The Missing in Sednaya Prison (ADMSP) (2020), Sednaya Prison During The Syrian Revolution: Testimonies. Aziantep. https://admsp. org/wp-content/uploads/2020/07/Testimonies-EN-1-1.pdf (6 October 2020).

Brennan, T. (2004), Transmission of Affect (Ithaca, NY: Cornell University Press).

Filipović, A. (2018), 'Resonant masculinities: Affective co-production of sound, space, and gender in the everyday life of Belgrade', Serbia: NORMA 13, nos. 3-4: 213-226.

Goodman, S. (2012), Sonic Warfare: Sound, Affect and the Ecology of Fear (Cambridge, MA: MIT Press). 
Harlow, B. (1992), Barred: Women, Writing, and Political Detention (Middletown, CT: Wesleyan University Press).

Hirschkind, C. (2004), 'Hearing modernity: Egypt, Islam, and the pious ear', in V. Erlmann (ed), Hearing Cultures: Essays on Sound, Listening, and Modernity (New York: Berg Publishers), 131-152.

Howes, D. and C. Classen (2014), 'The politics of perception: Sensory and social ordering', in Ways of Sensing: Understanding the Senses in Society (New York: Routledge), 65-92.

Kapchan, D. (2015), 'Body', in D. Novak and M. Sakakeeny (eds), Keywords in Sound (Durham, NC: Duke University Press), 33-44.

Khoja-Moolji, S. (2016), 'The sounds of racialized masculinities: Examining the affective pedagogies of Allahu Akbar', Feminist Media Studies 16, no. 6: 1110-1113.

Larkin, B. (2013), 'The politics and poetics of infrastructure', Annual Review of Anthropology 42: 327-343. https://doi.org/10.1146/annurev-anthro-092412-155522.

Lefebvre, H. and C. Régulier (2004), 'The rhythmanalytical project', in Rhythmanalysis: Space, Time and Everyday Life, edited by Henri Lefebvre, 71-83. Translated by Stuart Elden and Gerald Moore (New York: Continuum).

LeVine, M. and M. F. Malmström (2019), 'Understanding the materiality of suspicion: Affective politics in MENA cities', in H. Yacobi and M. Nasasra (eds), Handbook for Cities in the Middle East (New York: Routledge), 136-152.

Malmström, M. F. (2015), 'Porous masculinities: Agential political bodies among male Hamas youth', Etnográfica 19, no. 2: 301-322. https://doi.org/10.4000/etnografica.4014.

Malmström, M. F. (2019), 'The Streets are Talking to Me': Affective Fragments in Sisi's Egypt (Berkeley: University of California Press).

Mbembe, A. (2019), Necropolitics (Durham, NC: Duke University Press).

Michaelson, R. (2018), 'Egypt's Nadeem Center for Torture Victims persists against odds'. DV. https://www.dw.com/en/egypts-nadeem-center-for-torture-victims-persistsagainst-odds/a-43388534 (accessed 10 September 2020).

Papaeti, A. (2020), 'On music, torture and detention: Reflections on issues of research and discipline, Transposition 2: 1-18.

Parker, J. E. K. (2019), Sonic lawfare: On the jurisprudence of weaponised sound, Sound Studies 5, no. 1: 72-96.

Peteet, J. M. (1994), 'Male gender and rituals of resistance in the Palestinian "Intifada": A cultural politics of violence'. American Ethnologist 21, no. 1: 31-49.

Rice, T. (2016), 'Sounds inside: Prison, prisoners and acoustical agency', Sound Studies 2, no. 1: 6-20. https://doi.org/10.1080/20551940.2016.1214455.

Schafer, R. M. (1977), The Tuning of the World (New York: A.A. Knopf).

Stewart, K. (2007), Ordinary Affects (Durham, NC: Duke University Press).

The Nadeem Center for Rehabilitation of Victims of Violence and Torture in Cairo (2014), We Are the Voice When You Want to Silence the World: Letters from behind Bars (Cairo: El Nadeem Center). 